\title{
The Effects of 12-Weeks in a Combined Exercise Program on the Self-Reliance Fitness and Growth Hormone in the Obese Elderly Women
}

\author{
Sang-Muk Park ${ }^{1}$ and Joung-OK Yang ${ }^{2}$ * \\ ${ }^{1}$ Academy of Continuing Education Gymnasium Manager, Dongju College, Busan 604-715, Korea \\ ${ }^{2}$ Division of Physical Education, Silla University, Busan 617-736, Korea
}

Received July 28, 2011 /Revised October 10, 2011 /Accepted October 172011

\begin{abstract}
The purpose of this study was to observe self-reliance fitness and growth hormones in obese elderly women. Twenty-four females over the age of 65 years, who did not exercise regularly, were chosen as test subjects. All subjects were evaluated pre- and post-test. The results of this study were as follows; Results related to the experimental group revealed that there were statistically significant differences between the mean scores pre- and post-test in self-reliance fitness. Results related to the experimental group revealed that there were statistically significant differences between the mean scores pre- and post-test in growth hormone. Overall, participation in a 12-week combined exercise program had a positive impact on the self-reliance fitness and growth hormone in the obese elderly women. Based on the results of this study, obese elderly women are encouraged to participate in a combined exercises program on a regular basis.
\end{abstract}

Key words : Combined Exercise Program, the Obese Elderly Women, self-reliance fitness, growth hormone

\section{서 론}

노인에게 있어서는 한 가지의 기능을 향상시키기 위한 특화 된 운동도 중요하지만, 일상생활능력과 관련된 전반적인 체력 의 향상을 도모하는 운동이 더욱 필요하며, 고령기에는 미국 체육학회(American Alliance of Health, Physical Education, Recreation, \& Dance: AAHPERD)가 제안한 건강관련 체력에 민첩성과 협응성 등을 포함한 기능관련 체력의 유지 및 향상 에 중점을 두어야 한다[7]. 지속적인 단일운동이 노인들의 건 강과 체력을 향상시킨다는 선행연구 결과들을 고려해 볼 때, 그 중에서 복합운동프로그램은 유산소운동의 혈당, 인슐린 감 수성 개선 효과[45], 저항운동의 골격근 내에서의 당대사 개선 과 근육량 증가로 인한 인슐린 감수성 개선효과[11] 등이 복합 적으로 작용하여 비만에 따른 여러 가지 질환을 예방하고 개 선시키는 이상적인 방법이라고 할 수 있다. 노인을 위한 운동 지침을 살펴보면, 걷기, 달리기, 수영, 자전기타기와 같은 대근 육의 리드미컬한 활동을 포함하는 운동을 실시하여야 하고, 운동 목적이 근력을 증가시키는 것이라면 비교적 높은 강도의 점진적 저항운동을 적어도 주당 2회 이상 실시하여야 한다[1]. 많은 노인전문가들은 연구를 통해 노인들의 체력을 부상 없이 향상시키기 위한 효과적인 운동방법을 제시하고 있는데, 노인 들에게 필요한 체력은 일상생활을 남의 도움 없이 스스로 생 활해 나갈 수 있는 자립생활체력이 중요하며, 이러한 체력 증

*Corresponding author

Tel : +82-51-999-5336, Fax : +82-51-999-5576

E-mail : joyang@silla.ac.kr
진을 위한 적절한 운동방법은 근력이나 유연성, 조정력을 향 상시키고, 운동프로그램은 전도의 가능성이나 골절의 발생을 줄일 수 있는 방법이어야 한다[19]. 더불어 유연성, 평형성, 그 리고 민첩성을 증진시키는 신체활동과 허약한 노인에게 있어 보행능력을 향상시키기 위해서는 일반적으로 하체 근력과 평 형성의 개선이 중요하다. 노화는 신체활동, 호르몬 분비의 감 소 등과 밀접한 관련이 있으며, 여러 가지 요인들이 노화와 관련되어 있지만, 특히 성장호르몬의 분비가 급격하게 감소하 는 60세 전·후에 노화가 촉진됨에 따라 가장 중요한 노화관 련 호르몬 중의 하나로 성장호르몬이 간주되고 있다[5]. 성장 호르몬은 주로 간에서 존재하는 성장호르몬 수용체와 결합하 여 혈중 인슐린양성인자-I (Insulin like Growth Factor- I : IGF- I )의 생성을 촉진하여 혈중 인슐린양성인자-I 농도를 상승시키고, 장골의 성장판 연골세포의 분화 및 증식을 일으 켜 성장을 촉진하는 것으로 알려져 있다[2]. 또한, 성장호르몬 의 성장작용은 간, 골격근, 연골 및 다른 조직에서 혈중 인슐린 양성인자-I 의 합성과 분비를 촉진시키고, 인슐린과 길항작용 을 하여 글리코겐의 분해 작용, 당 신생 등을 증가시킴으로써 복부지방 분해, 세포 외액과 근육의 증가, 뼈 밀도의 증가 등과 같은 대사 개선 효과를 나타낸다[30]. 성장호르몬과 관련된 선 행연구들을 살펴본 결과 성장호르몬에 관한 대부분의 연구들 은 저 강도 및 고 강도 운동에서 모두 성장호르몬 분비가 유의 하게 증가하지만 연구 참여자들의 체력수준에 따라 달라지며, 저 강도 운동 시보다는 고 강도 운동 시에 성장호르몬이 분비 가 더 된다[9]. 우리나라 65세 이상 노인들의 건강수준과 성장 호르몬이 관련된 연구에서 여성노인이 남성노인보다 평균수 
명, 만성질환비율, 비만비율이 높으며, 성별 간에도 건강 수준 의 차이가 있는 것으로 보고되고 있어[31], 노인 건강문제와 관련하여 성장호르몬과 여성노인을 대상으로 하는 체계적이 고 과학적인 연구의 필요성은 매우 시급한 것으로 사료된다. 따라서 본 연구의 목적은 65 세 이상의 비만 여성노인을 대 상으로 12 주 복합운동프로그램을 실시하여 자립생활체력과 성장호르몬에 미치는 영향을 구명함으로써 비만 여성노인의 건강한 삶을 위해 적합한 운동프로그램을 제공하는데 있다.

\section{재료 및 방법}

\section{대상 및 설계}

본 연구의 참여자는 $\mathrm{B}$ 광역시 $\mathrm{S}$ 지역에 거주하며, 신체질량 지수(BMI) $25 \mathrm{~kg} / \mathrm{m}^{2}$ 이상인 65 세 이상의 비만 여성노인들로 서 모든 검사 및 측정에 앞서 본 연구의 목적 및 진행에 대하여 이해하고 참여에 동의한 24 명을 대상으로 하였다. 참여자로 부터 연구시작 전 실험참여 동의서를 받았고 그룹은 무작위로 선정하여 복합운동집 단 $(\mathrm{n}=12)$, 통제집단 $(\mathrm{n}=12)$ 으로 구분하였 다. 대상자들의 신체적 특성은 Table 1과 같다.

\section{채혈 및 분석}

전혈에서 혈청, 혈장 분리 후 냉장 보관된 검체는 $\mathrm{GH}$ Daiichi Kit (Daiichi Radioisotope Laboratories, Ltd. Japan)를 사용하여 비경쟁반응(immunoradio metric assay)방법으로 측정하였으며, 고상법(solid phase)으로 항체가 피복된 구슬 (Beads)에 항원을 반응시킨 다음 표지항체(I125-Anti 항원)를 반응시켜 검체의 항원을 알리는 Sandwich 원리를 이용하여 분석하였다. 검사 시 혈압의 측정시간은 오전 09시부터 09시 30 분 사이로 동일하게 하여 측정하였다.

\section{운동방법}

복합운동프로그램은 Table 2와 같이 비만 여성노인에게 적 합한 유산소성 운동인 걷기운동, 평형성운동, 탄성밴드를 이 용한 근력운동, 요가운동을 혼합한 복합운동으로 구성하였다.
본 연구를 위한 12 주 복합운동프로그램은 Table 2 와 같다.

\section{자료처리}

본 연구에서 실시한 12 주 복합운동 전·후에 대한 측정치는 SPSS Windows 17.0 통계프로그램을 이용하여 모든 종속변인 들의 평균값과 표준편차를 산출하였다. 또한, 복합운동의 효 과 검증을 위한 통계분석을 실시하기 전 복합운동집단과 통제 집단간의 동질성 검증을 위해 각 측정항목을 종속변인으로 하는 독립 $t$-검정(independent $t$-test)을 실시하였으며, 그 결과 악력과 누웠다 일어서기를 제외한 모든 변인들에서 집단 간의 동질성이 검증되었다. 12 주 전 · 후의 각 집단 내 변인들의 변 화를 알아보기 위해 대응표본 $t$-검정(paired $t$-test)을 실시하였 다. 통계적 유의수준은 $a=0.05$ 로 하였다.

\section{결 과}

\section{자립생활체력의 변화}

12 주 복합운동 전 - 후에 따른 자립생활체력의 변화 결과는 Table 3과 같다.

$2 \mathrm{~kg}$ 아령들기의 경우 복합운동집단은 증가 $(4.75 \mathrm{~kg})$ 한 반 면 통제집단은 오히려 감소(-1.5 times/30 sec)하였다. 윗몸일 으키기의 경우 복합운동집단은 증가 $6.17 \mathrm{times} / 30 \mathrm{sec}$ )한 반 면 통제집단은 오히려 감소 $(-2.34$ times/30 sec)하였다. 의자앉 아일어서기의 경우 복합운동집단은 증가 $(5.83 \mathrm{times} / 30 \mathrm{sec})$ 한 반면 통제집단은 오히려 감소 $(-0.83$ times/30 sec)하였다. 좌전굴의 경우 복합운동집단은 증가 $(4.17 \mathrm{~cm})$ 한 반면 통제집 단은 오히려 감소 $(-0.82 \mathrm{~cm})$ 하였다. 눈뜨고 외발서기의 경우 복합운동집단은 증가 $(7.85 \mathrm{sec})$ 하였고, 통제집단 또한 증가 $(1.06 \mathrm{sec})$ 하였다. 최대보폭의 경우 복합운동집단은 증가 $(6.72$ $\mathrm{cm})$ 한 반면 통제집단은 오히려 감소 $(-3.71 \mathrm{~cm})$ 하였다. $10 \mathrm{~m}$ 최대보행의 경우 복합운동집단은 감소 $(-0.56 \mathrm{sec})$ 한 반면 통제 집단은 오히려 증가 $(0.35 \mathrm{sec})$ 하였다. $2.44 \mathrm{~m}$ 반환점 되돌아 앉기의 경우 복합운동집단은 감소 $(-0.26 \mathrm{sec})$ 한 반면 통제집단 은 오히려 증가 $(0.35 \mathrm{sec})$ 하였다. 안정시심박수의 경우 복합운

Table 1. The characteristics of the subjects (Mean \pm SD)

\begin{tabular}{lcc}
\hline Variable $(\mathrm{N}=24)$ & $\mathrm{A}(\mathrm{n}=12)$ & $\mathrm{B}(\mathrm{n}=12)$ \\
\hline Age $(\mathrm{yr})$ & $68.42 \pm 2.53$ & $67.17 \pm 2.36$ \\
Height $(\mathrm{cm})$ & $153.08 \pm 3.87$ & $154.79 \pm 5.67$ \\
Weight $(\mathrm{kg})$ & $59.32 \pm 3.29$ & $60.31 \pm 6.69$ \\
Fat $(\%)$ & $30.45 \pm 2.92$ & $29.40 \pm 4.41$ \\
BMI $\left(\mathrm{kg} / \mathrm{m}^{2}\right)$ & $25.36 \pm 2.12$ & $25.14 \pm 2.09$ \\
SBP $(\mathrm{mmHg})$ & $144.33 \pm 13.10$ & $141.58 \pm 11.18$ \\
DBP $(\mathrm{mmHg})$ & $90.50 \pm 10.62$ & $87.85 \pm 2.49$ \\
HR rest $(\mathrm{bpm})$ & $75.00 \pm 13.45$ & $64.92 \pm 10.08$ \\
\hline
\end{tabular}

Values are Means \pm SD. $\mathrm{N}=24$

A: composite training group, B: control group 
Table 2. The 12-week complex training program

\begin{tabular}{|c|c|c|c|}
\hline Exercise mode & Exercise component & $\begin{array}{l}\text { Exercise } \\
\text { time }\end{array}$ & $\begin{array}{l}\text { Exercise } \\
\text { intensity }\end{array}$ \\
\hline Warm-up & Warming up Stretching & $10 \mathrm{~min}$ & \\
\hline Walking exercise & $\begin{array}{l}5 \text { min walk lightly } \\
10 \text { min walk } \\
5 \text { min walk lightly }\end{array}$ & $20 \mathrm{~min}$ & $\begin{array}{c}\text { 1 12 wk } \\
\text { RPE 10 13 } \\
50 \sim 75 \% \text { HRmax }\end{array}$ \\
\hline Balanced star exercise & stand with one foot, walking three steps, walking a line: $3 \mathrm{~m}$ Walk & $10 \mathrm{~min}$ & \\
\hline Elastic band exercise & $\begin{array}{l}\text { Elbow sit-ups chest forward, } \\
\text { sit down and eight sheep Paddle, } \\
\text { sitting on top of your head, pushing, } \\
\text { bending biceps, } \\
\text { triceps, straighten, stand up and sat, } \\
\text { lay beolrigi, } \\
\text { lifting the legs down, laying the ankle bending, } \\
\text { lifting your upper body lying }\end{array}$ & $20 \mathrm{~min}$ & $\begin{array}{l}\text { 1 12 wk } \\
\text { RPE 12 13 } \\
10 \sim 15 \text { Set }\end{array}$ \\
\hline Yoga exercises & $\begin{array}{l}\text { jeongul stance, } \\
\text { side stance sukyigi, bats pose, } \\
\text { half spinal twist pose, bow pose, } \\
\text { Somerystance (transformation), } \\
\text { cat stance, } \\
\text { sphinx pose, } \\
\text { Fish pose, } \\
\text { knees to the chest waiting posture, } \\
\text { abdominal own stance, } \\
\text { posture Invoice }\end{array}$ & $15 \mathrm{~min}$ & $\begin{array}{c}\text { RPE 10 13 } \\
50 \sim 75 \% \text { HRmax }\end{array}$ \\
\hline Cool-down & Cool-down Stretching & $5 \mathrm{~min}$ & \\
\hline
\end{tabular}

동집단은 감소(-9.58 bpm)한 반면 통제집단은 오히려 증가 $(2.33 \mathrm{bpm})$ 하였다. 체중당 최대산소섭취량의 경우 복합운동집 단은 증가 $(2.8 \mathrm{ml} / \mathrm{kg} / \mathrm{min})$ 한 반면 통제집단은 오히려 감소 $(-1.17 \mathrm{ml} / \mathrm{kg} / \mathrm{min})$ 하였다. 최대산소섭취량의 경우 복합운동 집단은 증가 $(2.8 \mathrm{ml} / \mathrm{kg} / \mathrm{min})$ 한 반면 통제집단은 오히려 감소 $(-0.07 \mathrm{l} / \mathrm{min})$ 하였다. 대응표본 $t$-검정 결과에 의하면, 모든 자 립생활체력의 변인들에 대한 복합운동집단의 사전 - 사후 평 균값들 사이에는 통계적으로 유의한 차이가 나타났다( $p \times 0.01$, $p \times 0.001)$. 반면 통제집단의 경우 의자앉아일어서기, 눈뜨고 외 발서기, 안정시심박수에서는 통계적으로 유의한 차이가 나타 나지 않았다. 그러나 $2 \mathrm{~kg}$ 아령들기( $\beta \times 0.05)$, 윗몸일으키기 $(p<0.05)$, 좌전굴 $(p<0.05)$, 최대보폭 $(p<0.001), 10 \mathrm{~m}$ 최대보행 ( $p \times 0.05), 2.44 \mathrm{~m}$ 반환점 되돌아 앉기 $(p<0.001)$, 체중당 최대산 소섭취량 $(p<0.01)$, 최대산소섭취량 $(p<0.01)$ 에서는 통계적으로 유의성이 검증되었는데, 이러한 통계적 유의성은 부정적인 변 화를 의미하는 것이다.

\section{성장호르몬의 변화}

12 주 복합운동프로그램 전 · 후에 따른 성장호르몬의 변화 결과는 Table 4 와 같다.
성장호르몬의 경우, 복합운동집단은 증가 $(0.15 \mathrm{ng} / \mathrm{ml})$ 한 반면 통제집단은 오히려 감소 $(-0.08 \mathrm{ng} / \mathrm{ml})$ 하였다. 대응 $t$-검 정 결과에 의하면, 성장호르몬에 대한 복합운동집단의 사전 사후 평균값 사이에는 통계적으로 유의한 차이가 나타났다 $(p<0.001)$. 반면 통제집단의 경우 성장호르몬에서는 통계적으 로 유의한 차이가 나타나지 않았다.

\section{고 찰}

\section{자립생활체력의 변화}

노인들의 근골격계에 나타나는 노화현상은 근의 면적이나 근의 크기 감소 및 근력의 약화가 나타나고, 근지구력, 유연성, 민첩성도 저하됨으로 해서 결과적으로 낙상, 골절, 손상된 움 직임에 기여하는 기능적 감소로 나타날 수 있다[40,32]. 운동의 유효성을 알고 있음에도 불구하고 노인의 $60 \%$ 이상은 규칙적 인 운동을 하지 않는 것으로 보고되고 있다[7].

본 연구에서는 자립생활체력 중 근력과 근지구력을 평가하 기 위해 12 주 복합운동 실시 후 $2 \mathrm{~kg}$ 아령들기, 윗몸일으키기, 의자에 앉아일어서기를 측정한 결과 복합운동집단의 $2 \mathrm{~kg}$ 아 령들기는 $4.75 \mathrm{~kg}(24 \%)$, 윗몸일으키기는 6.17 times/30 sec 
Table 3. After 12-week complex training in changes of Self-reliance Fitness

\begin{tabular}{|c|c|c|c|c|c|}
\hline & Item & $\mathrm{N}=24$ & Pre $(\mathrm{M} \pm \mathrm{SD})$ & Post $(\mathrm{M} \pm \mathrm{SD})$ & $\mathrm{t}$ \\
\hline \multirow{6}{*}{ Strength } & \multirow{2}{*}{$\begin{array}{l}2 \mathrm{~kg} \text { lifting weights } \\
\text { (times } / 30 \mathrm{sec} \text { ) }\end{array}$} & $\mathrm{A}(\mathrm{n}=12)$ & $19.67 \pm 3.93$ & $24.42 \pm 2.99$ & $8.204^{* * *}$ \\
\hline & & $\mathrm{B}(\mathrm{n}=12)$ & $21.08 \pm 3.39$ & $19.58 \pm 2.61$ & $3.000^{*}$ \\
\hline & \multirow{2}{*}{$\begin{array}{l}\text { Sit-ups } \\
\text { (times/30 sec) }\end{array}$} & $\mathrm{A}(\mathrm{n}=12)$ & $17.50 \pm 5.38$ & $23.67 \pm 4.39$ & $4.675^{\text {** }}$ \\
\hline & & $\mathrm{B}(\mathrm{n}=12)$ & $22.42 \pm 7.03$ & $20.08 \pm 5.82$ & $2.482^{*}$ \\
\hline & \multirow{2}{*}{$\begin{array}{l}\text { Chair, stand up sit down } \\
\text { (times } / 30 \mathrm{sec} \text { ) }\end{array}$} & $\mathrm{A}(\mathrm{n}=12)$ & $21.42 \pm 2.61$ & $27.25 \pm 3.01$ & $10.383^{* * *}$ \\
\hline & & $B(n=12)$ & $22.33 \pm 4.53$ & $21.50 \pm 4.54$ & 1.283 \\
\hline \multirow{4}{*}{ Flexibility } & \multirow{2}{*}{ Jwajeongul (cm) } & $\mathrm{A}(\mathrm{n}=12)$ & $14.49 \pm 3.09$ & $18.66 \pm 2.32$ & $8.245^{* * *}$ \\
\hline & & $B(n=12)$ & $16.70 \pm 2.52$ & $15.88 \pm 2.21$ & $2.751^{*}$ \\
\hline & \multirow{2}{*}{$\begin{array}{l}\text { Keep your eyes open one leg stand } \\
\text { (sec) }\end{array}$} & $\mathrm{A}(\mathrm{n}=12)$ & $17.31 \pm 4.17$ & $25.16 \pm 4.96$ & $15.098^{* * *}$ \\
\hline & & $B(n=12)$ & $16.45 \pm 5.08$ & $17.51 \pm 5.34$ & 1.544 \\
\hline \multirow{4}{*}{ Balance } & \multirow{2}{*}{$\begin{array}{l}\text { The maximum stride length } \\
(\mathrm{cm})\end{array}$} & $\mathrm{A}(\mathrm{n}=12)$ & $45.90 \pm 9.53$ & $52.62 \pm 9.86$ & $10.984^{* * *}$ \\
\hline & & $\mathrm{B}(\mathrm{n}=12)$ & $50.10 \pm 8.60$ & $46.39 \pm 7.62$ & $9.084^{* * *}$ \\
\hline & \multirow{2}{*}{ Walking up to $10 \mathrm{~m}$ (sec) } & $\mathrm{A}(\mathrm{n}=12)$ & $6.77 \pm 0.45$ & $6.21 \pm 0.36$ & $7.076^{* * *}$ \\
\hline & & $B(n=12)$ & $6.52 \pm 0.68$ & $6.87 \pm 0.48$ & $2.471^{*}$ \\
\hline \multirow{4}{*}{ Agility } & \multirow{2}{*}{$\begin{array}{l}2.44 \mathrm{~m} \text { sitting back turning point } \\
(\mathrm{sec})\end{array}$} & $\mathrm{A}(\mathrm{n}=12)$ & $5.66 \pm 0.48$ & $5.40 \pm 0.58$ & $3.244^{* *}$ \\
\hline & & $\mathrm{B}(\mathrm{n}=12)$ & $5.43 \pm 0.38$ & $5.78 \pm 0.39$ & $7.787^{* * *}$ \\
\hline & \multirow{2}{*}{ Resting heart rate (bpm) } & $\mathrm{A}(\mathrm{n}=12)$ & $75.00 \pm 13.45$ & $65.42 \pm 7.59$ & $3.766^{* *}$ \\
\hline & & $\mathrm{B}(\mathrm{n}=12)$ & $64.92 \pm 10.08$ & $67.25 \pm 6.73$ & 0.929 \\
\hline \multirow{4}{*}{$\begin{array}{l}\text { Cardiorespiratory } \\
\text { endurance }\end{array}$} & \multirow{2}{*}{$\begin{array}{l}\text { Chejungdang maximum oxygen } \\
\text { uptake }(\mathrm{ml} / \mathrm{kg} / \mathrm{min})\end{array}$} & $\mathrm{A}(\mathrm{n}=12)$ & $23.05 \pm 3.83$ & $25.85 \pm 3.17$ & $9.464^{* * *}$ \\
\hline & & $\mathrm{B}(\mathrm{n}=12)$ & $24.46 \pm 3.64$ & $23.29 \pm 3.16$ & $3.680^{* *}$ \\
\hline & \multirow{2}{*}{$\begin{array}{l}\text { Maximum oxygen uptake } \\
(1 / \mathrm{min})\end{array}$} & $\mathrm{A}(\mathrm{n}=12)$ & $1.59 \pm 0.31$ & $1.73 \pm 0.29$ & $37.601^{* * *}$ \\
\hline & & $\mathrm{B}(\mathrm{n}=12)$ & $1.65 \pm 0.26$ & $1.58 \pm 0.28$ & $3.129 * *$ \\
\hline
\end{tabular}

Values are Means \pm SD. $\mathrm{N}=16$

A: composite training group, B: control group ${ }^{*} p<0.05^{* *} p<0.01{ }^{* * *} p<0.001$

Table 4. After 12-week complex training in changes of growth hormone

\begin{tabular}{ccccc}
\hline Item & $\mathrm{N}=24$ & Per $(\mathrm{M} \pm \mathrm{SD})$ & Post $(\mathrm{M} \pm \mathrm{SD})$ & $\mathrm{t}$ \\
\hline Growth Hormone & $\mathrm{A}(\mathrm{n}=12)$ & $0.53 \pm 0.15$ & $0.68 \pm 0.14$ & $7.629^{* * *}$ \\
$(\mathrm{ng} / \mathrm{ml})$ & $\mathrm{B}(\mathrm{n}=12)$ & $0.56 \pm 0.11$ & $0.51 \pm 0.94$ & 1.974 \\
\hline
\end{tabular}

Values are Means \pm SD. $\mathrm{N}=24$

A: composite training group, B: control group

${ }^{*} p<0.05^{* *} p<0.01{ }^{* * *} p<0.001$

(35\%), 의자에 앉아일어서기는 5.83 times/sec $(27 \%)$ 가 통계적 으로 유의하게 증가한 것으로 나타났다. 이러한 결과의 근본 적인 이유는 바로 복합운동프로그램 중 걷기운동과 탄성밴드 운동의 구성에서 찾아 볼 수 있을 것이다.

본 연구 결과는 여성노인을 대상으로 유산소와 탄성밴드를 이용한 저항성운동, 복합운동을 실시한 결과 의자에 앉아 일 어서기에서 통계적 유의성이 검증되어 하지 근지구력의 향상 에 효과적이었다는 보고[20]와 65세 이상 여성노인을 대상으 로 유산소운동인 걷기와 아령, 탄성밴드를 이용한 근력운동을 주 2회 60 분간 실시한 결과 운동 실시 후에 여성노인의 근력과 근지구력이 향상되었다[16]는 몇몇 선행연구들에서 나타난 비 만 여성노인에 대한 복합운동의 효과를 지지해주고 있다. 본
연구의 복합운동프로그램 중 걷기운동이 노인의 근력과 근지 구력에 영향을 줄 수 있는지에 대해 알아 볼 필요가 있는데, 이에 대해 규칙적인 운동경험이 없는 65 세 이상의 여성노인 총 45 명을 대상으로 통제집단 15 명, 간헐적 걷기집단 15 명은 매회 10 분의 걷기를 4 시간 간격으로 하루 3 회 실시하고, 지속 적 걷기집단 15 명은 1 일 1 회 30 분의 지속적인 걷기를 주 3 회 12 주간 실시한 결과, 의자에 앉아 일어서기로 실시한 검사에 서는 시기의 주 효과와 상호작용이 유효했으며, 간헐적 걷기 집단과 지속 보행군이 사전검사에 비해 통계적으로 유의한 향상이 있었다[21]. 또한, 걷기를 꾸준히 실시해온 여성들에서 골소실율이 낮아지는 것으로 결과가 나타나 꾸준한 걷기운동 은 전완의 요골골밀도에도 영향을 주어 상지근력에도 관련이 
있다고 주장함으로써[41], 노인의 근력과 근지구력 향상에 대 해 본 연구에서의 복합운동프로그램 구성요소의 하나인 걷기 운동 효과를 어느 정도 지지해주고 있다. 따라서 본 연구에서 근력과 근지구력이 유의하게 향상된 이유는 복합운동 종목 중 탄성밴드를 이용한 근저항운동과 걷기운동이 상 - 하체의 근 기능에 긍정적인 결과를 가져오고, 평형성운동과 요가운동 이 신체 안정성에 영향을 주는 복합적인 작용으로 인해 결과 적으로 비만 여성노인들의 활동력을 증가시킴으로써 통계적 유의성이 검증된 것으로 여겨진다. 본 연구에서 12 주 복합운 동 후 비만 여성노인들의 유연성의 변화를 살펴보기 위해 좌 전굴을 측정한 결과, 복합운동집단의 좌전굴은 $4.17 \mathrm{~cm}(29 \%)$ 나 향상된 것으로 나타났다. 이러한 결과는 12 주간 주 3 회 10 가지의 서로 다른 형태의 상지와 하지 운동을 순환식으로 실 시한 결과, 좌전굴에 있어 유의하게 나타났고[46], 65세 이상 여성 노인들을 대상으로 10 주간 스트레칭 프로그램 실시 후 운동군에서 척추가동범위가 $8.2 \mathrm{~cm}$ 증가하였고, 몸통 및 고관 절 가동범위의 경우는 $4.6 \mathrm{~cm}$ 가 증가하여 몸통 및 고관절 가동 범위에서 통계적으로 유의한 변화가 있었다[22]. 그리고 여성 노인을 대상으로 6 개월간 복합운동을 실시한 결과 유연성이 유의하게 향상되었고[24], 12주 동안 여성노인들을 대상으로 걷기운동, 조깅, 자전거타기운동을 실시한 결과 좌전굴이 유 의하게 증가하였다[3]는 선행연구들에서 나타난 비만 여성노 인의 유연성 향상에 대한 복합운동의 효과에 대해 어느 정도 지지해 주고 있다. 본 연구에서도 유연성 향상 결과는 최대운 동범위의 $80 \sim 90 \%$ 에서 실시된 스트레칭과 요가운동이 비만 여 성노인의 유연성을 향상시킨 것으로 여겨지며, 결과적으로 연 령이 증가함에 따라 관절의 유연성이 감소하는 것은 운동부족 이 큰 원인으로 작용하기 때문에 노인을 대상으로 한 운동 적용 시 요가와 스트레칭과 같은 유연성 프로그램을 병행한 복합운동프로그램이 구성된다면 부상 예방 뿐 만 아니라 신체 활동을 더욱 증가시킬 수 있으리라 판단된다.

본 연구에서 비만 여성노인의 평형성능력을 알아보기 위해 정적평형성인 눈뜨고 외발서기와, 최대보폭, 그리고 동적평형 성인 $10 \mathrm{~m}$ 최대보행을 측정한 결과 복합운동집단의 평형성 변인인 눈뜨고 외발서기는 $7.85 \mathrm{sec}(45 \%)$ 가, 최대보폭은 6.72 $\mathrm{cm}(14.6 \%)$ 가, $10 \mathrm{~m}$ 최대보행은 $0.56 \mathrm{sec}(8.3 \%)$ 로 향상된 것으 로 나타났다. 이러한 결과는 20대와 69세의 건강한 노인 그리 고 77세의 허약 노인의 최대보폭을 비교한 연구에서 건강한 노인의 경우 20 30대의 성인에 비해 최대 보폭에서 약 $16 \%$ 정도의 감소가 나타났고[33], 건강한 노인과 허약 노인을 비교 한 결과 약 $30 \%$ 의 차이가 나타나, 65 세 이상 노인 1,076 명을 대상으로 8 주간 주 3 회 근력운동과 균형운동의 복합운동을 실시한 결과 정적자세균형이 향상되어 짧은 운동기간에도 균 형 능력의 향상에 도움이 되었다[25]. 65세 이상 여성노인들에 있어 관절가동범위와 척추유연성의 감소는 평형성 유지능력 또한 저하되므로 정적평형능력의 향상을 위한 유연성 운동의
중요성에 대해 강조하였고[6], 스트레칭, 걷기, 자세조정, 협응 성 강화 등이 포함된 운동프로그램 참가가 균형과 가동성 향 상에 대한 유의성을 발견할 수 없었으나, 개선 가능성은 충분 하다[34]는 선행연구들과 거의 일치하는 것으로 나타났다. 역 시 여성노인을 대상으로 각각 저항성, 평형성, 유연성 운동트 레이닝 집단으로 구분하여 12 주간 주 2 회, 50 분간 운동을 실시 한 결과 저항성, 평형성 운동집단에서 균형 자신감이 유의하 게 증가[28]하였고, 평균 67세의 여성노인을 대상으로 36주간 주 3 회, 1 회 60 분간의 복합운동을 실시하여 $10 \mathrm{~m}$ 최대보행시 간이 유의하게 개선되었다[36]. 그리고 65세 이상 여성노인을 대상으로 탄력저항성 운동집단 17 명, 평형성 운동집단 17 명, 통제집단 18 명을 12 주간 주 3 회, 60 분씩 운동을 실시한 결과 노인의 균형자신감은 저항성운동에 비해 평형성운동이 보다 효과적이었다고 주장함으로써[42], 본 연구결과가 선행연구들 에서 나타난 비만 여성노인의 평형성에 대한 복합운동의 효과 를 지지해주고 있다. 이러한 결과의 근본적인 원인은 복합운 동프로그램 중 평형성운동의 효과라 추측되는데, 본 연구에서 흥미로운 결과는 총 80 분간의 운동프로그램 중 10 분간의 짧은 평형성운동의 구성만으로도 비만 여성노인들의 평형성이 증 가된 점이 주목할 만하다. 또한, 본 연구에서 정적평형성 향상 을 위한 프로그램인 한 발로 서기와 동적평형성을 향상시키기 위한 한줄 걷기와 3 단계 보행운동의 반복적 실시가 노인의 평형성 향상을 이끌어내는데 충분한 가치가 있음을 시사하는 결과라고 생각된다. 더불어 본 연구에서의 다양한 운동이 복 합적으로 허리와 하지의 근육을 자극하여 주동근과 길항근을 동시에 수축시킬 수 있는 능력이 향상됨으로써 신체의 안정성 이 높아져 평형성 향상에 도움이 되었다고 판단되는데, 이에 대한 근거로, 한 가지 형태의 운동보다 다양한 형태의 운동을 복합적으로 실시한 결과 평형성이 향상되었다는 주장이[15] 노인의 평형성에 대한 복합운동의 효과를 어느 정도 지지해주 고 있다.

민첩성을 평가하기 위한 방법으로서 $2.44 \mathrm{~m}$ 반환점 되돌아 앉기 동작은 버스에서 내리기, 부억일 보기, 화장실 가기, 전화 받기 위해 일어서기 등 빠른 동작이 필요한 과제에서 동적평 형성과 함께 민첩성을 평가하는데 중요한 요소로서, 낙상과 관련된 체력요인을 평가하는데 높은 신뢰도와 타당도를 가진 검사방법으로 알려져 있다[17]. 본 연구에서는 민첩성을 평가 하기 위해 $2.44 \mathrm{~m}$ 반환점 되돌아 앉기 동작을 측정하였는데, 12 주 복합운동 후 복합운동집단의 $2.44 \mathrm{~m}$ 반환점 되돌아 앉기 동작은 $0.26 \mathrm{sec}(4.6 \%)$ 가 감소하여 긍정적인 변화가 나타났다. 선행연구를 살펴보면, 6 개월 이상 규칙으로 운동에 참여한 여 성노인(수영, 게이트볼)과 일반노인을 대상으로 연구한 결과, 운동에 참여한 여성노인에게서 민첩성에서도 높은 상관성이 나타났다는 보고[24]와 유산소 리듬 운동프로그램을 실시한 결과 여성노인의 민첩성 요소에 긍정적인 효과가 있었다[23]. 그리고 65세 이상 남·여 노인을 대상으로 유산소운동과 저항 
성운동을 주당 3회 실시한 결과 기능관련 체력요소인 민첩성 에서 운동참여효과가 있었다는 주장[37]을 살펴볼 때, 본 연구 결과가 선행연구들의 결과와 거의 일치하고 있다. 본 연구에 서 민첩성 향상의 결과는 복합운동의 영향에 의해 체중, 체지 방률 등 신체조성이 개선됨에 따라 민첩성이 향상된 것으로 추측되며, 비만 여성노인에게 있어 민첩성의 향상은 위급한 상황 발생 시 재빨리 위기를 모면할 수 있는 일상생활에서의 안전과도 밀접한 관계가 있는 것으로 판단되므로 비만 여성노 인들에 있어 본 연구를 통해 향상된 민첩성은 매우 중요한 의미를 가질 수 있을 것으로 생각된다.

본 연구에서 비만 여성노인의 심폐지구력을 알아보기 위해 12 주 복합운동 후 안정시심박수, 최대산소섭취량, 체중당 최 대산소섭취량을 측정하였다. 복합운동집단의 심폐지구력 변 인 중 체중당 최대산소섭취량은 $2.8 \mathrm{ml} / \mathrm{kg} / \mathrm{min}(12.1 \%)$, 최대 산소섭취량은 $0.141 \mathrm{ml} / \mathrm{kg} / \mathrm{min}(8.8 \%)$ 이 복합운동집 단에서 통계적으로 유의하게 증가한 반면, 안정시심박수는 $9.58 \mathrm{bpm}$ $(12.8 \%)$ 이 통계적으로 유의하게 감소한 것으로 나타났다. 이 러한 결과는 복합운동을 통해 여성노인들의 심폐지구력을 향 상시킬 수 있는 선행연구자들의 주장을 지지해주고 있는데, 복합운동이 노인여성의 심폐지구력을 향상시킨 결과를 살펴 보면, 65 세 이상 노인 31명을 대상으로 16 주간 지구성운동집 단과 저항성운동집단 그리고 복합운동집단으로 나누어 운동 의 효과를 비교한 결과, 노인의 심폐지구력을 증가시키는데 단일운동보다 복합운동이 더욱 효과가 있었다[15]. 또한, 비만 여성노인을 대상으로 1 회 60 분 주 4 일 12 주간 유산소운동과 요가운동을 실시한 결과 운동집단에서 최대산소섭취량과 체 중당 최대산소섭취량이 각각 증가하여 신체기능이 개선되었 고[37], 근력운동과 혼합된 유산소운동은 유산소운동을 실시 했을 때보다 최대하 및 최대지구력 시간이 크게 증가하였다 [43]고 주장함으로써, 본 연구결과가 선행연구들에서 주장하 고 있는 여성노인의 심폐지구력에 대한 복합운동의 효과를 지지해주고 있다. 많은 학자들 역시 심폐지구력은 최대산소섭 취량이나 대사량(metabolic equivalents)으로 측정되는 유산 소능력으로 심혈관질환을 가진 사람이나 정상인 모두에게 사 망을 야기하는 주요 예측인자이며, 심혈관질환 위험요인과 유 의한 상관관계를 나타낸다[26]. 또한, 최대산소섭취량과 운동 에 관한 연구들의 대부분이 지속적인 운동은 최대산소섭취량 과 체중당 최대산소섭취량을 증가시켜 심폐기능을 개선시킨 다[35]. 노인의 심박수에 대해 젊은 성인과 비교할 경우, 최대 심박수는 10년 간 5 10회 줄어들지만, 안정시심박수는 젊은 성인의 것과 크게 다르지 않으며, 일반적으로 유산소운동에 의하여 낮아지는데 이것은 부교감 신경인 미주신경작용의 상 승으로 심장기능 향상에 기인한 것이다[8]. 즉 장기간 유산소 성 운동을 한 사람은 비록 심박수는 낮지만 1회 박출량이 증가 함으로써 보다 효율적으로 조직에 혈액을 공급할 수 있는 것 으로 추측된다. 결과적으로 연구에서 나타난 심폐지구력의 향
상은 걷기 운동 시 목표심박수를 유지하기 위하여 휴대용 심 박수계를 착용하고, 자신의 심박수를 체크하면서 중강도의 운 동수준을 유지한 것이 비만 여성노인의 중추신경계에 긍정적 인 변화를 준 것으로 추측되며, 더불어 1회 박출량(Stroke Volume: SV), 심박출량(Cardiac Output: Q), 그리고 산소섭취 량의 증가가 심장의 기능적 개선으로 이어져 비만 여성노인의 심폐지구력이 향상된 것으로 판단된다.

\section{성장호르몬의 변화}

노화관련 호르몬 중 성장호르몬은 신체전반에 걸쳐 성장, 발육을 촉진시키는 호르몬으로 세포의 크기, 세포 수, 유사분 열 등을 증가 또는 촉진시키는 작용과 세포 간의 아미노산을 이동시키고, 세포로 하여금 아미노산을 합성하는데 도움을 줄 뿐 만 아니라 단백질을 이용하여 세포를 복구시키고 재생시키 는 역할까지 한다. 일반적으로 운동은 성장호르몬의 분비를 직접 자극함으로써 조직의 성장을 자극하게 한다. 이는 성장 호르몬의 방출을 억제시키는 소마토스타틴(somatostatin)의 생산을 억제시킴으로써 성장호르몬의 방출을 억제시키는 호 르몬의 생산을 자극하고 근육의 성장과 비대를 유발하는 것으 로 알려져 있다[10]. 본 연구에서는 12 주 복합운동 후 비만 여 성노인을 대상으로 노화관련 호르몬 중의 하나인 성장호르몬 을 측정한 결과 복합운동집단의 성장호르몬이 $0.15 \mathrm{ng} / \mathrm{ml}$ $(28.3 \%)$ 가 통계적으로 유의하게 증가한 것을 알 수 있었다. 이러한 결과는 보통 성장호르몬의 분비가 급격하게 감소하는 60세 전 · 후에 노화과정이 촉진되는 것으로 알려져 있는 것을 고려해 볼 때 본 연구에서의 성장호르몬 증가는 매우 의미 있는 결과라 판단된다. 이와 관련된 선행연구를 살펴보면, 운 동에 의한 성장호르몬의 분비는 운동 시작 후 수분이 지난 뒤에 나타나다가 운동강도가 계속적으로 증가하면 성장호르 몬의 생산은 급격히 증가한다[18]. 저항 운동에 대한 성장호르 몬의 반응에서도 운동강도와 지속 시간이 성장호르몬의 분비 에 중요한 역할을 하며, 운동 중에 나타나는 현상이지만 체온 이 증가하면 성장호르몬의 농도도 증가한다[12]. 또한, 성인들 을 대상으로 2개월에서 24개월까지의 지구성 트레이닝을 규 칙적으로 시킨 결과, 높은 성장호르몬 촉진반응을 나타내었다 [29]. 65 세 여성노인 14 명을 통제집단(7명), 복합운동집단(7명) 으로 나누어 복합운동(유산소운동: Treadmill Running, $60 \%$ $\mathrm{HRmax}$, 저항운동: $1 \mathrm{RM}$ 의 $60 \%$, 종목당 10 12회, $3 \mathrm{set}$ )을 주 4 회 60 분간 실시한 결과 복합운동집단의 성장호르몬 수치가 통계적으로 유의하게 증가하였다[13]. 이상과 같이 운동이 성 장호르몬에 미치는 영향에 대한 선행연구들을 살펴본 결과, 규칙적인 운동이나 신체활동은 부작용 없이 성장호르몬의 분 비를 촉진시키는 것으로 알려진 바와 같이[14], 노화와 신체활 동에 대한 항산화 및 내분비학적 접근을 통하여 노화지연 및 노인의 신체적, 정신적 건강과 관련된 다양한 연구들이 제시 되고 있으나, 성장호르몬의 향상을 위해 복합운동과 운동강도 
의 중요성에 대해 주장하고 있는 유산소성 운동 실시 후 성장 호르몬 수치에서 모호한 결과를 보인 연구들[38]은 거의 운동 강도를 간과했기 때문이며, 이에 반해 운동강도를 $70 \%$ 이상 유지한 연구들에서는[9,27] 대부분 통계적으로 유의한 증가를 보여 이러한 점을 고려할 때 여러 가지 운동형태를 혼합한 복합운동이 성장호르몬에 의미 있는 운동형태라고 주장함으 로써 성장호르몬에 대한 복합운동의 효과를 지지해주고 있다. 유산소 운동은 30 분 이상 계속하지 않으면 지방연소의 효과가 없다고 한다. 그것은 지방이 분해되기까지 시간이 걸리기 때 문이다. 하지만 이 분해를 빠르게 하는 비책이 성장호르몬을 분비하는 것인데 성장호르몬은 지방분해기능을 가지고 있으 므로 성장호르몬의 분비를 늘리는 해답은 무산소 운동에 있 다. 무산소 운동이 지방을 없애주지는 않지만 성장호르몬 분 비를 촉진하여 지방을 분해하는 효과가 있다[35]. 본 연구에서 성장호르몬의 괄목할 만한 향상 결과는 복합운동에 의한 운동 적응력이 성장호르몬의 단백질 동화작용으로 인한 근력증가 와 함께 지방을 분해하여 복부비만 개선에 효과적이었다.

\section{References}

1. American College of Sports Medicine. 2000. ACSM'S Guidelines for Exercise Testing and Prescription. 6th (eds.), Philadelphia: Lippincott Williams \& Wilkins.6. 10. Chung, Y. S. 2000. Aging and growth hormone. Endocrinol. Metab. 18, 73-79.

2. Bright, G. M., A. D. Rogol, A. J. Johanson, and R. M. Blizzard. 1983. Short stature associated with normal growth hormone and decreased somatomedine $\mathrm{C}$ concentration: Response to exogenous growth hormone. Pediatrics 71, 576-580.

3. Brown, M. and J. Holloszy. 2002. Effects of walking, jogging and cycling on strength, flexibility, speed and balance in 60 to 72-year olds. Aging 5, 427-434.

4. Clark, B. A. 1989. Tests for fitness in older adults AAHPERD fitness task force. J. Articles; Reports-Descriptive 60, 66-71.

5. Chung, Y. S. 2000. Aging and growth hormone. Endocrinol. Metab. 18, 73-79.

6. Cho, S. K., J. P. Lee, J. K. Oh, and H. S. Kim. 2006. The effect of 12 weeks strengthening and stretching combined exercise for balancing ability in elderly women. J. Sport Leisure Studies 20, 53-64.

7. Crespo, C. J., S. J. Keteyian, G. W. Heath, and C. T. Sempos. 1996. Leisure-time physical activity among US adults. Results from the third national health and nutrition examination survey. Arch Intern. Med 156, 93-98.

8. Cooper, K. H., M. L. Pollick, R. P. Martin, S. R. White, A. C. Linnerud, and A. Jackson. 1976. Physical fitness level vs selected coronary risk factors. Across-sectional study. JAMA 236, 166-169.

9. Consitt, L. A., J. L. Copeland, and M. S. Tremblay. 2001. Hormone responses to resistance vs. endurance exercise in premenopausal females. Can. J. Appl. Physiol. 26, 574-587.
10. Fan, T. D., P. E. Molina, M. C. Gelato, and C. H. Lang. 1994. Differential tissue regulation of insulin-like growth factor- I content and binding protein after endotoxin. Endocrinology 134, 1685-1692.

11. Goodyear, L. J. and B. B. Kahn. 1998. Exercise, glucose transport, and insulin sensitivity. Annu. Rev. Med 49, 235-261.

12. Hong, Y. J., K. S. Koo, and Y. K. Baek. 2008. Effects on elderly women's aging hormone by participating in Korean dance and administering melatonin. Korean J. Physical Education 47, 523-532.

13. Han, J. K. 2008. The impact of long team combined exercise on aging related hormone in elderly women. Sports Sci. 17, 24-30.

14. Hakkinen, K., A. Pakarinen, W. J. Kraemer, R. U. Newton, and M. Alen. 2000. Basal concentrations and acute responses of serum hormones and strength development during heavy resistance training in middle-aged and elderly men and women. J. Gerontol. A Biol. Sci. Med Sci. 55, B95-105.

15. Izquierdo, M., J. Ibanez, K. Hakkinen, W. J. Kraemer, J. L. Larrion, and E. M. Gorostiaga. 2004. Once weekly combined resistance and cardiovascular training in healthy older men. Med Sci. Sports Exerc. 36, 435-443.

16. Jeong, S. T., T. H. Nam, and T. W. Kim. 2003. Effects of the health-related physical fitness on walking and resistance exercise of the older women-comparisons of exercise and detraining period. Korean J. Physical Education 42, 793-805.

17. Jin, H. M. and C. G. Kang. 2007. The change of older women's ADL, IADL and physical fitness after remedial exercise at an institution for the aged. J. Korean Physical Edu. Association Girls Woman 21, 77-90.

18. Jung, D. S. 1995. Sports science information: muscle function training jugihwa. Sports Sci. 74, 43-48.

19. Kohrt, W. M., S. A. Bloomfield, K. D. Little, M. E. Nelson, and V. R. Yingling. 2004. American College of Sports Medicine Position Stand: physical activity and bone health. Med Sci. Sports Exerc. 36, 1985-1996.

20. Kim, H. S. 1999. Effect of self-paced exercise on the daily living functional fitness in elderly women. Exerc. Sci. 8, 485-493.

21. Kim, S. H. 2009. The effects of 12 weeks of circuit exercise on obesity, physical fitness and metabolic syndrome index in elderly obese women. J. Korea Gerontological Society. 29, 823-835.

22. Kim, I. S., I. S. Jeong, and H. M. Jeong. 2004. The Effects of a Stretching Exercise Program in Elderly Women. J. Korean Academy Nursing 34, 123-131.

23. Kim, J. H. and Y. S. Park. 2000. The effect of aerobic rhythmical exercise program on physical fitness, self-efficacy and quality of life in elder. J. Korean Academy Nursing 14, 22-25.

24. Kwon, J. J. and K. J. Kim. 2003. ADL, IADL and fitness in the female olders participating swimming and gate ball. Korean J. Growth Development 11, 1-11.

25.. Kwon, O. Y., S. C. Houng, and J. M. Kyung. 1998. Characteristics of fall incidence in an elderly community 
population and the effects of exercise training on strength and balance for elderly fallers. Korea Public. Health Res. 24, 27-40.

26. Kemi, O. J., P. M. Haram, J. P. Loennechen, J. B. Oses, T. Skomedal, U. Wisloff, and Ø. Ellingsen. 2005. Moderate vs. high exercise intensity: differential effects on aerobic fitness, cardiomyocyte contractility, and endothelial function. Cardiovasc. Res. 67, 161-172.

27. Kanaley, J. A., J. Y. Weltman, J. D. Veldhuis, A. D. Rogol, M. L. Hartman, and A. Weltm. 1997. Human growth hormone respnse to repeated bouts of aerobic exercise. Can. J. Appl. Physiol. 83, 1756-1761.

28. Lie-Ambrose, T., K. M. Khan, J. J. Eng, S. R. Lord, and H. A. Mckay. 2004. Balance confidence improves with resistance or agility training. Increase is nat correlated with objective changes in fall risk and physical abilities. Gerontology 50, 373-382.

29. Luger, A., B. Watschinger, P. Deuster, T. Svovoda, M. Clodi, and G. P. Chorousos. 1992. Plasma growth hormone and prolactin responses to grade level of acute exercise and to a lactate infusion. Neuroendocrinology 56, 122-117.

30. Munzer, T., S. M. Harman, P. Hees, E. Shapiro, C. Christmas, and M. F. Bellantoni. 2001. Effects of GH and/or sex steroid administration on abdomianl subcutaneous and visceral fat in healthy aged women and men. J. Clinical Endoclinol. Metabolism 86, 3604-3610.

31. Moon, S. S. and J. J. Nam. 2001. Health status of elderly in Korea -fous on physical health and disability of elderly women. J. Korea Gerontological Society 21, 15-29.

32. Marcell, T. J. 2003. Sarcopenia: causes, consequences, and preventions. J. Gerontology 58, 911-916.

33. Medell, J. L. and N. B. Alexander. 2000. A clinical measure of maximal and rapid stepping in order women. $J$. Gerontology 55, 429-433.

34. Means, K. M., D. E. Rodell, P. S. O'Sullivan, and L. A. Cranford. 1996. Rehabilitation of elderly fallers: pilot study of a low to moderate intensity exercise program. Arch Phys. Med Rehabil. 77, 1030-1036.

35. Masashi, S. 2010. 1 degrees temperature people life. Seoul: Book Publishing narawon, 6-17.

36. Park, S. K. 2002. The effects of exercise for preventing fall on postural sway, BMD and gait ability in elderly women.
Korean J. Physical Education 41, 583-594.

37. Park, S. K., Y. C. Kwon, E. H. Kim, and J. K. Park. 2009. Effect of yoga and walking exercise on physical function, carotid artery structure and function in elderly obese women. Korean J. Physical Education 48, 495-502.

38. Park, I. R. 2004. The effects of complex exercise program on Body composition, Growth hormone and IGF-1 of obese girls in middle school. Korean J. Physical Education 43, 419-427.

39. Roemmich, J. N. and A. D. Rogol. 1997. Exercise and growth hormone: Dose one affect the other. J. Pediatr. 131, S75-80.

40. Spirduso, W. W., K. L. Francis, and P. G. MacRae. 2005. Physical dimensions of aging, 2nd (eds.), Champaignurbana, IL: Human Kinetics.

41. Sandler, R. B., J. A. Cauley, D. L. Hom, D. Sashin, and A. M. Kriska. 1987. The effects of walking on the cross-sectional dimensions of the radius in postmenopausal women. Calcif. Tissue Int. 41, 65-69.

42. Sung, S. C. and M. G. Lee. 2007. Effects of resistance and balance exercise training on isokinetic function, postural stability, and balance efficacy in elderly women. Korean $J$. Sport Sci. 18, 21-33.

43. Spina, R. J., T. Ogawa, T. R. Miller, W. M. Kohrt, and A. A. Ehsani. 1993. Effect of exercise training of eft ventricular performance in older women free of cardiopulmonary disease. Am J. Cardiol. 71, 99-104.

44. Santiage, M. C. 1995. Failure of 40 weeks of brisk walking to alter blood lipids in normolipemic women. Can. J. Appl. Physiol. 20, 417-428.

45. Thompson, P. D., D. Buchner, I. L. Pina, G. J. Balady, M. A.Williams, B. H. Marcus, K. Berra, S. N. Blair, F. Costa, B. Franklin, G. F. Fletcher, N. F. Gordon, R. R. Pate, B. L. Rodriguez, A. K. Yancey, and N. K. Wenger. 2003. Exercise and physical activity in the prevention and treatment of atherosclerotic cardiovascular disease: a statement from the council on clinical cardiology (subcommittee on exercise, rehabilitation, and prevention) and the council on nutrition, physical activity, and metabolism (Subcommittee on Physical Activity). Circulation 107, 3109-3116.

46. Whitehurst, M. A., B. L. Johnson, C. M. Parker, L. E. Brown, and A. M. Ford. 2005. The benefits of a functional exercise circuit for older adults. J. Strength Cond Res. 19, 647-651. 


\section{초록 : 12주 복합운동이 비만 여성노인의 자립생활체력과 성장호르몬에 미치는 영향}

\section{박상묵 ${ }^{1}$ 양정옥 ${ }^{2}$ *}

(동주대학교 평생교육원, ${ }^{2}$ 신라대학교 체육학부)

본 연구는 규칙적으로 운동에 참여하지 않는 65 세 이상의 비만 여성노인 24 명을 대상으로 12 주 복합운동이 비만 여성노인의 자립생활체력과 성장호르몬에 미치는 영향을 구명하기 위하여 운동 전과 운동 후의 자립생활체 력 변인과 성장호르몬을 측정하여 비교분석하였다. 본 연구 결과 자립생활체력은 복합운동집단이 유의하게 증가 하였고, 성장호르몬도 복합운동집단 유의하게 증가를 하였다. 이상의 결과 규칙적인 12 주 복합운동이 비만 여성 노인들의 자립생활체력과 성장호르몬의 변화에 긍정적인 영향을 미친 것으로 생각되며, 향후 비만 여성노인들의 체력과 신체여건에 알맞은 효율적인 복합운동프로그램이 지속적으로 개발되고 노년기의 건강유지 및 삶의 질을 높이는데 도움을 줄 수 있는 후속 연구가 다양하게 이루어져야 할 것으로 사료된다. 